\title{
KNOWLEDGE MANAGEMENT DALAM ORGANISASI
}

\author{
Made Adi Widyatmika ${ }^{1}$, Tjokorda Putra ${ }^{2}$, Made Novia Indriani ${ }^{3}$ \\ 1,2,3 Program Studi Teknik Sipil FT Universitas Hindu Indonesia \\ Jln. Sangalangit, Denpasar-Bali \\ 19adi.widyatmika@unhi.ac.id, cok.putra@unhi.ac.id, ${ }^{3}$ madenovia@gmail.com;
}

\begin{abstract}
ABSTRAK
Knowledge Management (KM) adalah suatu pengorganisasian pengetahuan yang dimiliki oleh individu dalam sebuah organisasi. Dengan knowledge management, suatu pengetahuan yang dimiliki individu akan dapat menjadi pengetahuan organisasi sehingga bermanfaat bagi organisasi terutama dalam meningkatkan daya saing bisnis organisasi. Dengan banyaknya knowledge management yang telah diterapkan di beberapa organisasi di Indonesia, maka perlu dilakukan review kembali mengenai penelitian terkait bagaimana implementasi knowledge management pada organisasi komersial dan organisasi pendidikan. Metode penelitian yang digunakan adalah observasi dan study literatur. Dari hasil penelitian tersebut didapat kan bahwa implementasi knowledge management pada organisasi komersial PT Telkom Indonesia berdasarkan pengukuran kinerja dinyatakan sedang yaitu bahwa pengetahuan dalam kampiun belum memberikan hasil kinerja pegawai menjadi lebih maksimal. Sedangkan implementasi knowledge management pada organisasi pendidikan ITB Bandung, menunjukkan bahwa kebijakan teknis mendukung untuk manajemen pengetahuan digambarkan dalam visi, misi dan tujuan, penerapan manajemen pengetahuan dilihat dari aspek orang dilakukan melalui pengembangan kompetensi sumber daya manusia, proses manajemen pengetahuan sejalan dengan "Tridharma Perguruan Tinggi dengan penggunaan teknologi informasi. Untuk membuat pengetahuan tacit baru dapat dilakukan dengan beberapa cara, antara lain melalui pertemuan, lokakarya, seminar, dan lain-lain.
\end{abstract}

Kata Kunci: knowledge management, implementasi, organisasi komersial, organisasi pendidikan

\section{PENDAHULUAN}

Abad ke-21 dikenal sebagai era pengetahuan dan informasi. Negaranegara di dunia selalu berupaya untuk meningkatkan pengetahuan dan keterampilan masyarakatnya sebagai sebuah kekuatan. Pengetahuan menjadi aset yang bermanfaat dalam menghadapi persaingan global dalam berbagai bidang. Perkembangan inilah yang memicu organisasi-organisasi, baik organisasi komersial maupun non komersial seperti pendidikan, menyadari pentingnya peran pengetahuan dalam peningkatan kualitas. Dari sudut pandang ini, sebuah organisasi dipandang sebagai sebuah tubuh pengetahuan yang utuh (body of knowledge) yang tersusun dari pengetahuan-pengetahuan individual (Jakubik, 2007; Ramakrishnan dan Yasin, 2012). Nonaka dan Takeuchi (dalam Ubon dan Kimble, 2002) menyatakan bahwa agar pengetahuan 
dalam suatu organisasi dapat ditransformasi dari dimensi individu ke dimensi kolektif atau dari bentuk tacit ke bentuk explicit maka organisasi dapat memberikan peluang bagi orangorang untuk saling berinteraksi secara langsung (face to face). Atas dasar konsepsi inilah, muncul suatu upaya tata kelola pengetahuan dalam organisasi yang disebut dengan manajemen pengetahuan (knowledge management). Jadi, ide dasar dari konsep knowledge management adalah penyebaran dan penggunaan kembali pengetahuan oleh orang lain dalam satu organisasi (Razaghi et.al, 2013; Yoo dan Ginzberg, 2005).

Dewasa ini pengelolaan pengetahuan atau yang biasa disebut knowledge management menjadi salah satu cara alternatif yang digunakan dalam mencapai keunggulan kompetitif dari suatu organisasi. Dalam knowledge management dilakukan suatu pengelolaan yang menggunakan pengetahuan sebagai aset utama. Hal ini sesuai dengan apa yang diungkapkan Paul Martin (dalam Widayana, 2005: 5) bahwa pengetahuan dan inovasi akan menjadi bahan baku dari abad 21 . Francis Bacon's (dalam Sangkala, 2007: 5) juga mengungkapkan bahwa "knowledge itself power" yang diartikan bahwa di dalam era ekonomi baru abad dua puluh satu ini kita telah bergerak ke suatu dunia dimana berbagi pengetahuan (sharing knowledge) adalah power. Oleh karena itu daya saing perusahaan hakikatnya berasal dari pengetahuan.

\section{Knowledge}

management merupakan suatu pengorganisasian pengetahuan yang dimiliki oleh individu dalam suatu organisasi. Menurut Bergerson (2003), knowledge management merupakan suatu pendekatan yang sistematik untuk mengelola aset intelektual dan informasi lain sehingga memberikan keunggulan bersaing bagi perusahaan (Bergerson dalam Sangkala, 2007: 8). Dengan knowledge management maka pengetahuan akan dapat dikelola dengan baik, sehingga pengetahuan individu yang beragam menjadi mudah dipadukan agar dapat menjadi pengetahuan organisasi.

Banyak organisasi yang sudah melakukan implementasi knowledge management. Namun tidak sedikit pula organisasi yang tidak berhasil dalam menerapakan knowledge management. Lucier dan Torsiliera (dalam Chua, et al..2005: 7) mengungkapkan bahwa banyak laporan mengenai kegagalan program knowledge management. Yaitu $84 \%$ organisasi yang telah mengadopsi program knowledge management tidak mendapatkan dampak yang signifikan terhadap keberhasilan organisasi.

Banyak organisasi sudah mengadaptasi konsepsi ini dalam meningkatkan kualitas organisasi. Namun organisasi-organisasi yang telah mengadopsi konsepsi adalah yang bersifat komersial. Knowledge management belum banyak diterapkan pada organisasi- organiasi pendidikan, seperti sekolah, yang merupakan lembaga pendidikan yang merupakan organisasi yang aktivitasnya berkaitan dengan pengetahuan harus memanfaatkan konsepsi manajemen pengetahuan untuk meningkatkan performa organisasi.

\section{TEORI DAN METODE PENELITIAN \\ Knowledge dan Knowledge Management \\ Pengetahuan merupakan hasil proses melalui interaksi sosial dengan orang}


lain dan lingkungan untuk menjadi tujuan kebenaran (Nonaka,I at.al, 2008). Knowledge memiliki peran penting untuk mendukung budaya organisasi dan pemanfaatan teknologi informasi dalam melakukan knowledge transfer sebagai bagian integral dari knowledge sharing (Al-Gharibeh, K.M.,2011) . Konseptual data ke knowledge dilakukan melalui hirarki data, informasi, knowledge ke wisdom dan evaluasi dari understanding (Uriarte, Jr.F.A. 2008) sebagaimana disajikan pada gambar 2.1 berikut:

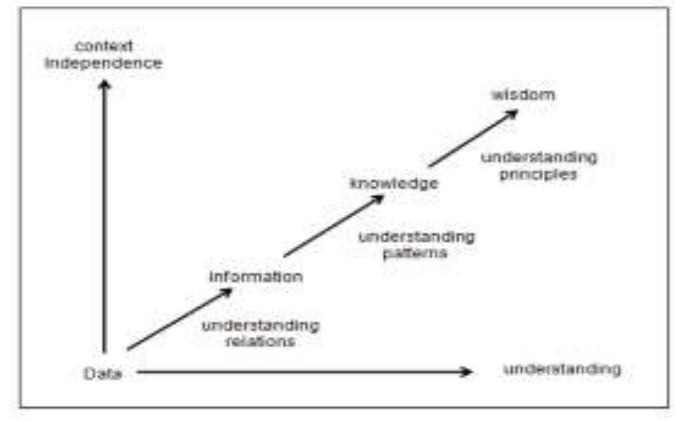

Gambar 2.1 Konseptual data ke Knowledge

Sumber : Uriarte, Jr.F.A (2008)

Data merupakan simbol-simbol dari fakta- fakta yang terkumpul, kemudian data itu diolah untuk memahami hubungan data dan informasi, sehingga informasi dapat dimanfaatkan untuk menjawab pertanyaan tentang "who", "what", "where" dan "when". Setelah informasi dimiliki merupakan aplikasi dari data dan informasi menjadi knowledge untuk menjawab pertanyaan "how". Sedangkan understanding berguna untuk mengapresiasi pertanyaan "why". Kemudian Wisdom merupakan evaluasi dari understanding.

Knowledge merupakan informasi yang berasal dari data yang diolah menjadi informasi sehingga dapat diakses oleh manusia yang terjadi melekat dengan kehidupan manusia sepanjang hayat yang dapat mengembangkan kecerdasan sehingga bagi manusia knowledge merupakan instrumen kehidupan yang membuat manusia memiliki kemampuan untuk memecahkan masalah kehidupan. Knowledge dapat membuka tabir kebodohan, tabir ketidaktahuan, dari tidak mengerti merubah menjadi mengerti karena ada knowledge pemahaman aspek dari kecerdasan. Untuk menggabungkan pengalaman baru dan informasi agar tidak terjadi stagnasi maka learning tidak boleh berhenti, untuk terus mengembangkan dan menciptakan knowledge baru, karena jika tidak ada pengembangan dan penciptaan yang terus menerus akan terjadi stagnasi. Pengembangan knowledge sifatnya dinamis dan tidak pernah berhenti selama manusia masih berfikir.Knowledge diperoleh melalui yang terjadi melekat dengan kehidupan manusia sepanjang hayat melalui proses belajar, sebagaimana tertuang dalam Undang-Undang Republik Indonesia Nomor 20 Tahun 2003, tentang Sistem Pendidikan Nasional.

Knowledge Management secara umum merupakan serangkaian praktik organisasi baru dengan relevansi yang besar dalam ekonomi pengetahuan. Knowledge management menyepakati serangkaian proses dan praktik 
secara sengaja yang dirancang untuk mengoptimalkan penggunaan ilmu pengetahuan. Dengan kata lain, untuk meningkatkan efisiensi alokasi di bidang produksi pengetahuan, distribusi dan penggunaan (Talisayon,S (2013). Dalam implementasi knowledge management baik di sektor bisnis maupun institusi pendidikan tentu tidak terlepas dari peran sumber daya manusia people, processes, dan technologies (Dalkir, K. (2005). Institusi Pendidikan dalam hal ini perguruan tinggi dalam menjalankan peran dan fungsinya dapat memanfaatkan knowledge management untuk mengintegrasikan pemahaman yang komprehensif, dan merefleksikan dampak kemajuan informasi (Petrides \& Nguyen, 2006). Dengan demikian, implementasi knowledge management diharapkan dapat meningkatkan mutu dan daya saing perguruan tinggi.

American Productivity and Quality Centre (APQC) mendefinisikan knowledge management sebagai strategi dan proses pengidentifikasian, menangkap dan mengungkit pengetahuan untuk meningkatkan daya saing bisnis (Sangkala, 2007: 7). Knowledge management terkait dengan peningkatan efektifitas organisasi. Konsentrasi terhadap knowledge management dilakukan karena knowledge management dipercaya dapat memberikan kontribusi kepada vitalitas dan kesuksesan perusahaan. Sehingga dalam organisasi, knowledge management dapat menjadi usaha untuk meningkatkan pengetahuan yang berguna dalam organisasi.

Knowledge dibagai dalam dua jenis yaitu tacit knowledge dan explicit knowledge (Polayi, M. 1968). Tacit knowledge merupakan knowledge yang diam dalam benak manusia yang berbentuk intuisi, judgement, skill, values dan bilief yang sangat sulit diformulasikan dan di share dengan orang lain. Sedangkan explicit knowledge adalah knowledge yang dapat atau sudah terkodifikai dalam bentuk dokumen atau bentuk berwujud lainnya sehingga dapat dengan mudah ditransfer dan didistribusikan dengan menggunakan berbagai media berupa formula, kaset/CD video dan audio, spesifik produk manual. Kedua jenis knowledge tacit dan explicit tersebut, oleh Nonaka dan Takeuchi (2008),dikonversi menjadi empat jenis proses konversi untuk menghasilkan pengetahuan baru melalui socialization, externalization, combination dan internalization atau lebih dikenal dengan Nonaka's SECI model sebagaimana disajikan pada gambar 2.2 berikut: 


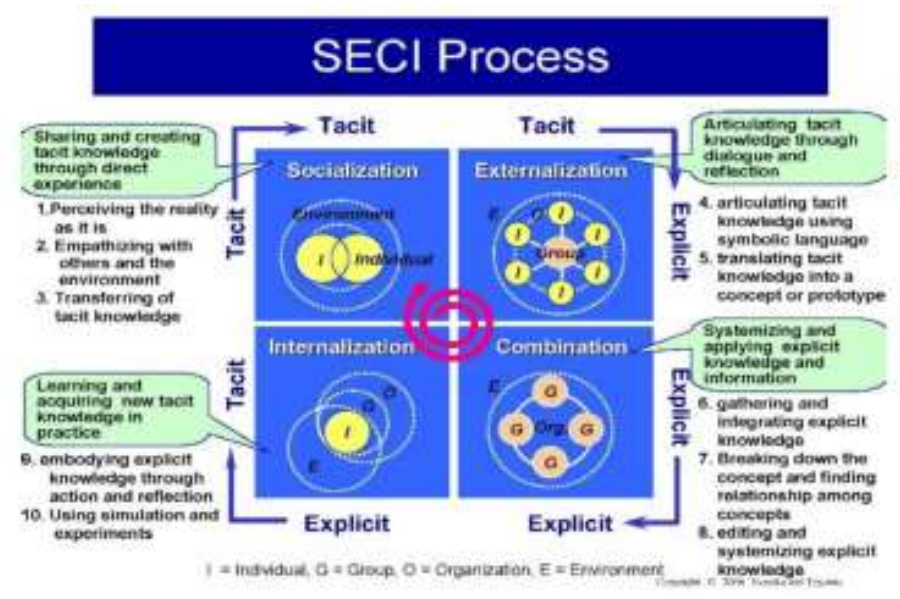

Gambar 2.2 Model SECI Process

Sumer Nonaka (2008:19)

Sosialisasi (socialization), dalam tahap ini, pengetahuan tacit individu dibagi melalui pengalaman bersama dalam interaksi sosial sehari- hari untuk membuat pengetahuan tacit baru. Eksternalisasi (Externalization), proses untuk mengartikulasi tacit knowledge menjadi explicit knowledge. Kombinasi (Combination), proses mengkombinasikan antar explicit knowledge yang dipunyai oleh individu yang berbeda, kemudian disusun ke dalam system knowledge management. Internalisasi (Internalization), proses peningkatan knowledge sumber daya manusia, dimana semua dokumen, data, dan informasi yang telah tersimpan melalui database organisasi dapat dibaca dan dimanfaatkan oleh semua orang, dan untuk mengakses knowledge tersebut dapat dilakukan melalui media intranet/internet. Dengan demikian, pengetahuan eksplisit, seperti konsep produk atau prosedur manufaktur, telah untuk diaktualisasikan melalui tindakan, refleksi, dan praktek sehingga dapat diinternalisasikan sebagai pengetahuan sendiri. Misalnya program pelatihan dapat membantu peserta untuk memahami diri mereka sebagai bagian dari organisasi sekitarnya.
Dengan membaca dan merefleksi diri tentang informasi dalam dokumen atau manual tentang pekerjaan mereka dan organisasi, peserta dapat menginternalisasi pengetahuan eksplisit ini dan memperkaya pengetahuan tacit mereka sendiri. Pengetahuan eksplisit juga dapat diwujudkan melalui simulasi atau percobaan. Dengan memahami SECI model seperti terlihat pada gambar di atas, maka organisasi dalam hal ini pendidikan tinggi perlu menyadari bahwa pengetahuan yang berawal dari masing-masing individu agar menjadi milik organisasi, harus mampu memfasilitasi, mendukung, dan menstimulasi pengetahuan individu menjadi pengetahuan organisasi melalui knowledge sharing dan ditunjang oleh sarana dan prasarana yang memadai dengan menggunakan teknologi informasi.

Knowledge Management secara umum merupakan serangkaian praktik organisasi baru dengan relevansi yang besar dalam ekonomi pengetahuan. Knowledge management menyepakati serangkaian proses dan praktik secara sengaja yang dirancang untuk mengoptimalkan penggunaan ilmu pengetahuan. Dengan kata lain, untuk 
meningkatkan efisiensi alokasi di bidang produksi pengetahuan, distribusi dan penggunaan .

\section{Implementasi Knowledge Management}

Dalam implementasi knowledge management baik di sektor bisnis maupun institusi pendidikan tentu tidak terlepas dari peran sumber daya manusia people, processes, dan technologies (Dalkir, K.(2005). Institusi Pendidikan dalam hal ini perguruan tinggi dalam menjalankan peran dan fungsinya dapat memanfaatkan knowledge management untuk mengintegrasikan pemahaman yang komprehensif, dan merefleksikan dampak kemajuan informasi (Petrides \& Nguyen, 2006). Dengan demikian, implementasi knowledge management diharapkan dapat meningkatkan mutu dan daya saing perguruan tinggi.

Dalam konteks implementasi knowledge management sumber daya manusia (people) bukan sistem, tetapi organisasi dapat memberdayakan sumber daya manusia untuk sharing dan manage knowledge sebagaimana dikemukakan Petrides dan Nodine (2003, hlm.11) bahwa people not systems, manage knowledge. But organizations can promote policies and practices that help people share and manage knowledge. Melalui praktik dan memperomosikan kebijakan manage knowledge organisasi dapat memanfaatkan sumber daya untuk mencapai produktivitas organisasi di berbagai bidang sehingga mampu bersaing dengan menggunakan asset intelektual yang juga sebagai human capital. Demikian pula hasil bahwa keberhasilan implementasi Knowledge Management System (KMS) dapat meningkatkan produktivitas organisasi diberbagai bidang.

\section{Metode Penelitian}

Penelitian menggunakan metode deskriptif melalui hasil observasi dan study literature. Mereview kembali penelitian terkait implementasi knowledge management pada organisasi komersial yaitu pada PT Telkom Indonesia dan implementasi knowledge management pada organisasi pendidikan di Institut Teknologi Bandung.

\section{HASIL DAN PEMBAHASAN Implementasi Knowledge Management di PT. Telekomunikasi Indonesia}

Pegawai PT Telkom sama dengan pegawai pada umumnya dimana mereka juga membutuhkan pengetahuan untuk melakukan pekerjaan mereka. Dari hasil kuisoner dapat diketahui bahwa kebutuhan pengetahuan pegawai paling besar adalah pengetahuan mengenai produk dan layanan perusahaan sebesar $55,4 \%$. Pengetahuan tersebut dibutuhkan pegawai karena PT Telkom merupakan perusahaan layanan jasa telekomunikasi, sehingga banyak pegawai membutuhkannya untuk mengetahui dan memahami apa saja yang menjadi hal utama dalam produk dan jasa yang disediakan oleh PT Telkom. Sehingga dapat disimpulkan bahwa kebutuhan pengetahuan yang dibutuhkan pegawai PT Telkom merupakan pengetahuan yang berhubungan dengan bidang pekerjaannya.

Dalam memenuhi kebutuhan tersebut, pegawai Telkom menggunakan berbagai sumber referensi seperti media cetak (buku/majalah/koran), hasil penelitian dan seminar, mengunduh dari internet, dari kampiun dan sharing dengan 
teman. Dan yang paling banyak dinyatakan responden adalah referensi pengetahuannya dari mengunduh di internet sebesar 16,9\%. Banyaknya pegawai yang memanfaatkan internet untuk memenuhi kebutuhan informasi dikarenakan internet yang menyediakan berbagai macam informasi yang dapat diperoleh dengan mudah.

Evaluasi kinerja dalam evaluasi implementasi knowledge management digunakan sebagai cara untuk menilai kinerja sumber daya manusia yang telah mengimplementasikan knowledge management yang ada dengan ikut aktif didalamnya dan melakukan berbagi pengetahuan di dalam kampiun. Dalam pengukuran evaluasi kinerja ini terdapat tujuh variabel yaitu dengan mengukur kinerja ternilai pegawai kemudian kualitas keputusan bagi kinerja pegawai berdasar pengetahuan yang didapatkan, kepuasan pegawai terhadap pengetahuan bagi pekerjaannya, kerjasama pegawai dalam pekerjaannya, peningkatan semangat pegawai dalam bekerja dengan pengetahuan yang didapatkannya, kegunaan pengetahuan bagi pekerjaan pegawai, dan inovasi yang diciptakan pegawai dalam pekerjaannya dari pengetahuan yang didapatkannya.

Sebesar $\quad 76 \%$ responden menyatakan bahwa pengetahuan dalam kampiun dapat membantu dalam menyelesaikan pekerjaan. Di dalam kampiun pengetahuan terdapat dalam berbagai sub yaitu pengetahuan dalam sub media \& edutainment, pengetahuan dalam sub sales, marketing \& service, pengetahuan dalam sub business serta pengetahuan dalam sub finance. Semua sub pengetahuan dinyatakan pegawai dapat membantu menyelesaikan pekerjaan. Pengetahuan yang paling dapat membantu untuk menyelesaikan pekerjaan dinyatakan oleh responden adalah pengetahuan dalam sub media $\&$ edutainment sebesar $21 \%$. Tetapi pengetahuan dalam sub lain juga dinyatakan responden dapat membantu menyelesaikan pekerjaan. Hasil tersebut menunjukkan bahwa semua sub pengetahuan dalam kampiun digunakan oleh pegawai untuk membantu menyelesaikan pekerjannya.

Selain dapat membantu menyelesaikan pekerjaan, dalam kampiun juga terdapat pengetahuan yang dapat membantu memperbaiki kesalahan dalam pekerjaan. Hal tersebut diungkapkan oleh sebesar $50 \%$ responden. Pengetahuan yang dapat membantu memperbaiki kesalahan paling banyak terdapat dalam sub pengetahuan media \& edutainment serta dalam sub sales, marketing \& service masing-masing sebesar $32 \%$. Hasil tersebut dapat dibuktikan bahwa dalam kampiun ada pengetahuan yang membantu memperbaiki kesalahan dalam pekerjaan. Sedangkan masih ada 50\% responden yang menyatakan di kampiun tidak ada pengetahuan yang membantu memperbaiki kesalahan pekerjaan, responden lebih memilih melakukan pencarian pengetahuan untuk membantu memperbaiki kesalahan pekerjaannya dari sharing dengan teman atau bertanya kepada teman daripada harus mencari di kampiun.

Hal diatas menunjukkan bahwa sebenarnya pegawai sudah melakukan sharing pengetahuan terkait pekerjaan dengan pegawai lain, atau yang sering disebut sebagai knowledge sharing. PT Telkom membuat dan 
mengembangkan kampiun sebagai media untuk mengelola pengetahuan pekerjannya termasuk juga knowledge sharing dengan menyediakan salah satunya adalah forum diskusi pegawai. Hanya saja beberapa pegawai belum terbiasa dengan penggunaan media untuk knowledge sharing.

Evaluasi kinerja juga dapat dilihat dari efisiensi waktu dalam melakukan pekerjaan. Dengan adanya kampiun diharapkan pegawai semakin efisien dalam mengerjakan pekerjaan mereka. sebesar $60 \%$ responden menyatakan pengetahuan dalam kampiun dapat membantu untuk efisiensi kerja. Efisiensi menurut Sedarmayanti (2001:112) adalah perbandingan terbaik antara hasil yang diperoleh dengan kegiatan yang dilakukan. Bekerja dengan efisien adalah bekerja dengan gerakan, usaha, waktu dan kelelahan yang sedikit mungkin. Untuk memperoleh hasil yang memuaskan, PT Telkom membuat kampiun dengan harapan bahwa pegawai akan dapat bekerja lebih efisien dengan didukung adanya banyak pengetahuan yaznng ada di dalamnya untuk membantu pekerjaan. Oleh karena itu, hasil kerja akan dapat meningkat. Sehingga perusahaan akan semakin meningkat juga produktifitas dan kinerjanya dan berimbas pada peningkatan pendapatan di perusahaan.

Kemudian, sebesar $56 \%$ responden menyatakan bahwa pengetahuan dalam kampiun dapat membantu pegawai untuk pengambilan keputusan lebih cepat serta lebih baik. Drucker (1998) menyatakan bahwa knowledge dapat mengubah sesuatu atau seseorang, yaitu ketika informasi menjadi dasar untuk bertindak, atau ketika informasi tersebut memampukan seseorang atau institusi untuk mengambil tindakan yang berbeda atau tindakan yang lebih efektif. Tetapi sebesar 53,6\% responden menyatakan keputusan tersebut tidak dapat digunakan untuk seluruh anggota unit kerja. Adanya kampiun diciptakan dengan menyediakan berbagai pengetahuan yang dapat digunakan untuk pengambilan keputusan dan keputusan tersebut dapat menjadikan praktek kerja pegawai menjadi lebih baik. Tetapi keputusan yang telah diambil, belum dapat digunakan oleh semua anggota unit kerja.

Selain dapat membantu pengambilan keputusan, pengetahuan dalam kampiun juga dapat memberikan kepuasan bagi pegawai. Kepuasan pegawai merupakan suatu hal yang dapat tercipta apabila ada persamaan antara harapan dan persepsi pegawai mengenai pengetahuan di kampiun. Sebanyak $38 \%$ pegawai mengungkapkan bahwa mereka puas terhadap pengetahuan dalam kampiun. Pegawai menyatakan puas karena pengetahuan dalam kampiun dapat menambah wawasan, dalam kampiun terdapat contohcontoh pengetahuan untuk pengambilan keputusan dan dalam pengetahuan di kampiun terdapat solusi penyelesaian masalah yang dapat diterapkan dalam pekerjaan. Tetapi besaran jumlah pengetahuan yang sesuai dengan kebutuhan dapat diperoleh pegawai hanya sebanyak 1 sampai 3 pengetahuan saja menurut $74 \%$ pegawai. Agar kemungkinan pegawai menemukan pengetahuan lebih banyak sesuai kebutuhannya di kampiun maka pegawai seharusnya dapat menambah intensitas akses per tahun dan serta menambah lama waktu mengaksesnya. 


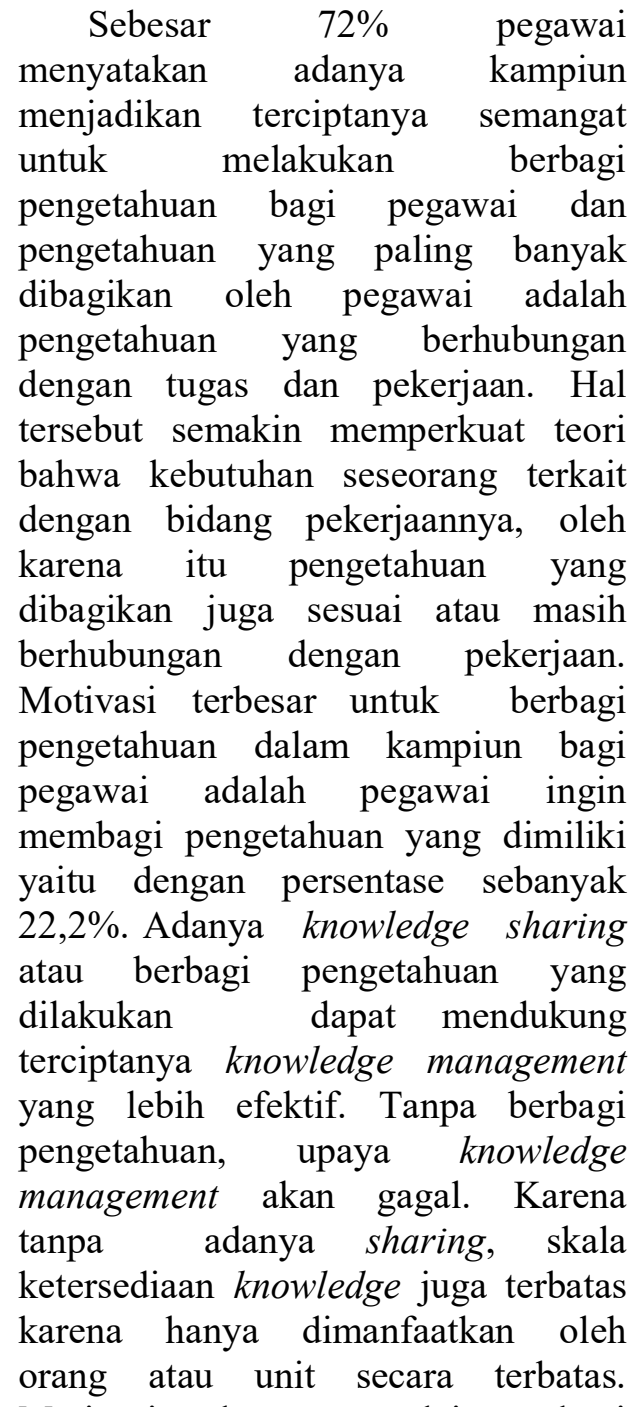

Motivasi terbesar yang lainnya bagi pegawai dalam berbagi pengetahuan di kampiun adalah untuk mendapatkan reward yaitu sebesar $11,2 \%$.

Pengetahuan dalam kampiun memiliki banyak daya guna bagi pegawai yang mengakses kampiun. Daya guna paling besar dari pengetahuan yang didapatkan pegawai dalam kampiun adalah pengetahuan dalam kampiun dapat menjadi sumber untuk meningkatkan kompetensi sebesar 12\%. Sehingga dengan meningkatkan kompetensi, pegawai dapat memiliki nilai kompetensi yang tinggi yang dapat menjadi salalh satu faktor untuk dipertimbangkan dalam menaikkan jabatan.

Selain memiliki daya guna sebagai sumber meningkatkan kompetensi, pengetahuan dalam kampiun juga dapat sebagai sumber inovasi sebesar 8\% karena sebesar $76 \%$ responden menyatakan pengetahuan dalam kampiun menjadikan pegawai lebih kreatif. Tetapi sebesar 24\% responden menyatakan pengetahuan dalam kampiun tidak menjadikan mereka lebih kreatif karena beberapa alasan, responden mengungkapkan bahwa pengetahuan dalam kampiun hanya digunakan untuk menambah wawasan saja. Sehingga dapat dianalisis bahwa apapun pengetahuan dalam kampiun sebenarnya memiliki banyak daya guna apabila pegawai mau melakukan pencarian pengetahuan dalam kamiun dan memanfaatkan pengetahuan tersebut dengan baik, lebih baik lagi apabila pengetahuan dalam kampiun dapat menciptakan suatu inovasi bagi kinerja pegawai agar lebih baik.

Dari hasil pengukuran evaluasi kinerja yang didapatkan, maka apabila dianalisis secara menyeluruh didapatkan hasil pengukuran evaluasi kinerja dengan penilaian sedang sebesar sebesar $42 \%$. Hasil tersebut dapat menjadi suatu penilaian bahwa kinerja ternilai pegawai kemudian kualitas keputusan bagi kinerja pegawai berdasar pengetahuan yang didapatkan, kepuasan pegawai terhadap pengetahuan bagi pekerjaannya, kerjasama pegawai dalam pekerjaannya, peningkatan semangat pegawai dalam bekerja dengan pengetahuan yang didapatkannya, kegunaan pengetahuan bagi pekerjaan 
pegawai, dan inovasi yang diciptakan pegawai dalam pekerjaannya dari pengetahuan yang didapatkannya memiliki tingkat pengukuran dalam kategori sedang.

Berdasarkan evaluasi kinerja pegawai yang mengakses kampiun dapat dibuktikan bahwa kampiun belum dapat memberikan hasil kinerja pegawai untuk menjadi lebih maksimal dengan berdasar pengetahuan yang ada dalam kampiun. Padahal tujuan dari diciptakannya kampiun adalah untuk dapat digunakan sebagai salah satu alat kerja bagi seluruh jajaran manajemen dan karyawan PT Telekomunikasi Indonesia untuk melakukan penciptaan (acquisition), saling berbagi (sharing) dan untuk pemanfaatan (utilization) knowledge yang dibutuhkan agar dapat membantu kinerja pegawai menjadi lebih baik.

Dari hasil analisa yang mendapatkan hasil pengukuran evaluasi kinerja berdasarkan pengetahuan kampiun memiliki kategori sedang. Maka dapat dianalisis bahwa pengetahuan kampiun belum dapat menjadikan kinerja pegawai menjadi lebih baik dan belum menjadikan pegawai lebih berbagi pengetahuan dalam organisasi untuk dapat membantu pegawai memilki kapabilitas yang berbeda serta pengetahuan kampiun belum dapat menjadikan kinerja pegawai dapat melakukan inovasi lebih hebat dan lebih cepat dari pesaing. Hal tersebut disebabkan karena organisasi belum memiliki kapasitas untuk menyerap atau mampu menggunakan pengetahuan terpenting dan mengakui nilai-nilai pengetahuan baru kemudian menyatukan berbagai pengetahuan dan menerapkannya. Sehingga dengan adanya hasil tersebut maka berdasarkan model Tiwana (1999) pada evaluasi implementasi knowledge management dilakukan evaluasi kinerja, setelah dilakukan hal tersebut maka perlu adanya perbaikan manajemen pengetahuan. Oleh karena itu, PT Telkom pada tahap selanjutnya harus melakukan banyak perbaikan dalam kampiun agar kampiun dapat berhasil sesuai tujuan awal yang ditetapkan.

\section{Implementasi Knowledge management di ITB}

Berdasar pada kebutuhan implementasi knowledge management di ITB sebagai upaya untuk meningkatkan kemampuan organisasi dalam mengelola asset intelektualnya sebagai upaya untuk meningkatkan mutu dan daya saing. Sesuai dengan visi dan misi ITB 2011-2015 "menjadi perguruan tinggi yang unggul, bermartabat, mandiri, dan diakui dunia serta memandu perubahan yang mampu meningkatkan kesejahteraan bangsa Indonesia dan dunia". Visi tersebut merupakan satu pernyataan mengenai bagaimana arah ITB ditetapkan. Kebijakan yang terkait dengan knowledge management di ITB sebagaimana telah ditetapkan dalam visi dan misi ITB dalam menghadapi era knowledge based economy diarahkan untuk mampu membangun dan menjalankan semangat entrepreneurial, khususnya didalam menjalankan program pendidikan, penelitian maupun pengabdian kepada masyarakat.

Salah satu upaya yang dilakukan ITB pada era knowledge based society/economy telah membuat kebijakan arah penelitian yang menjadi suatu kegiatan yang terinstitusi dalam bentuk prosedur standar riset sebagai 
"alat ukur" dan kualitas suatu riset untuk menghasilkan inovasi dan knowledge baru untuk mensejajarkan ITB dengan world class university. Kebijakan intellectual asset management dilakukan melalui pengembangan kompetensi sumber daya manusia dan sistem pengelolaan ITB dalam knowledge management. ITB memiliki komitmen terhadap penciptaan knowledge baru salah satunya melalui fungsi pengabdian pada masyarakat yaitu layanan pada bangsa untuk kemajuan ekonomi melalui diseminasi knowledge baru dan pemanfaatan teknologi.

Berkenaan dengan pengelolaan asset intelektual melalui knowledge management sebagaimana dalam Peraturan Menteri Pendayagunaan Aparatur Negara dan Reformasi Birokrasi Nomor 14 Tahun 2011 tentang Pedoman Pelaksanaan Program Manajemen Pengetahuan (Knowledge Management). Penerapan knowledge management tersebut, dimaksudkan untuk meningkatkan kemampuan organisasi dalam mengelola aset intelektualnya berupa pengetahuan dan pengalaman yang ada. Tujuannya adalah memanfaatkan aset tersebut untuk mencapai kinerja organisasi yang lebih baik untuk mempercepat pencapaian tujuan pelaksanaan reformasi birokrasi. Penerapan reformasi birokrasi tersebut, tentu tidak hanya di instansi pemerintah, tetapi juga tidak terkecuali di institusi pendidikan tinggi negeri untuk meningkatkan kinerja, mutu dan daya saing.

Proses implementasi knowledge management di perguruan tinggi dari aspek sumber daya manusia perlu diselaraskan dengan fokus peningkatan tridharma perguruan tinggi. Peningkatan kemampuan modal manusia (human capital) memiliki peran penting untuk mendukung sistem knowledge management, dalam upaya peningkatan daya saing. Perguruan tinggi dalam upaya menigkatkan daya saingnya memiliki peluang besar melalui implementasi knowledge management dengan memanfaatkan aspek sumber daya manusia sebagai modal manusia (human capital) diselaraskan dengan visi dan misi perguruan tinggi.

Knowledge sharing di
perguruan tinggi pada aspek sosialisasi (socialization) terhadap pengetahuan tacit individu dibagi melalui pengalaman bersama dalam interaksi sosial sehari- hari untuk membuat pengetahuan tacit baru dilakukan melalui beberapa cara antara melalui rapat, workshop, seminar, dan lain sebagainya yang tujuannya adalah untuk menciptakan ilmu pengetahuan, teknologi, seni dan ilmu kemanusiaan untuk memimpin perkembangan dan perubahan masyarakat secara etis melalui kegiatan tridarma perguruan tinggi yang inovatif, bermutu dan tanggap terhadap perkembangan dan tantangan baik lokal maupun global. Eksternalisasi (Externalization) dilakukan untuk mengartikulasi tacit knowledge menjadi explicit knowledge. Kemudian untuk mendukung proses eksternalisasi tersebut, dengan mendokumentasikan hasil-hasil pertemuan berupa notulen rapat dan sejenisnya sehingga menjadi suatu konsep yang jelas, kemudian dipublikasikan agar dapat dimanfaatkan oleh pihak-pihak yang berkepentingan. Pengetahuan tacit dikumpulkan dalam tahap sosialisasi diartikulasikan sebagai pengetahuan eksplisit melalui proses eksternalisasi . Proses konversi knowledge (combination) di perguruan tinggi 
mengkombinasikan berbagai explicit knowledge tidak lain adalah menerapkan ilmu pengetahuan, teknologi, seni dan ilmu kemanusiaan untuk mewujudkan masyarakat kampus yang sejahtera dengan dukungan sumberdaya yang memadai. Dalam proses kegiatan belajar mengajar melalui salah satu pendekatan dengan mengkombinasikan interaksi tatap muka dan interaksi online yaitu penerapan blended learning dapat mengintegrasikan manfaat yang diperoleh dari knowledge management melalui e-learning yang ditujukan untuk meningkatkan kualitas pembelajaran di perguruan tinggi yang juga merupakan efektivitas online knowledge sharing behavior. Mengkombinasikan antar explicit knowledge yang dipunyai oleh individu yang berbeda, kemudian disusun ke dalam system knowledge management. Media yang digunakan untuk proses ini dapat dilakukan melalui intranet dengan membuat fitur forum diskusi (knowledge sharing) secara internal, dan database organisasi melalui internet untuk memperoleh sumber eksternal.

Internalisasi (Internalization). Proses peningkatan knowledge sumber daya manusia, dimana semua dokumen, data, dan informasi yang telah tersimpan melalui database organisasi dapat dibaca dan dimanfaatkan oleh semua orang, dan untuk mengakses knowledge tersebut dapat dilakukan melalui media intranet/internet.
Pengetahuan eksplisit dibuat dan dibagi di seluruh organisasi dan diubah menjadi diwujudkan, pengetahuan tacit selama proses internalisasi. Internalisasi knowledge di perguruan tinggi yaitu menerapkan ilmu pengetahuan, teknologi, seni dan ilmu kemanusiaan untuk melayani masyarakat, industri dan pemerintah dalam rangka meningkatkan kualitas kehidupan bangsa dan dunia secara berkelanjutan.

Disiplin yang terlibat dalam knowledge management adalah manajemen sumber daya manusia dan pengembangan manajemen, information communication technology (ICT) dan kecerdasan buatan/ artificial intelligence (AI), dan bisnis pendidikan, pendidikan semakin virtual. Bisnis pendidikan meliputi pendidikan virtual, bertanggung jawab untuk menciptakan beberapa masukan dalam proses belajar tetapi juga untuk membuat beberapa pengetahuan diekstrak diakses untuk setiap individu. Bisnis pendidikan dalam hal ini juga harus dilakukan dengan konten. Aspek knowledge sharing adalah pendidikan satu juga. Management knowledge, karena itu, perlu mengintegrasikan disiplin seperti manajemen sumber daya manusia, ilmu organisasi, ilmu pendidikan, kecerdasan buatan dan ilmu kognitif. Di bawah ini ditawarkan model hipotetik peningkatan implementasi knowledge management perguruan tinggi secara efektif sebagaimana gambar 3.1 berikut : 


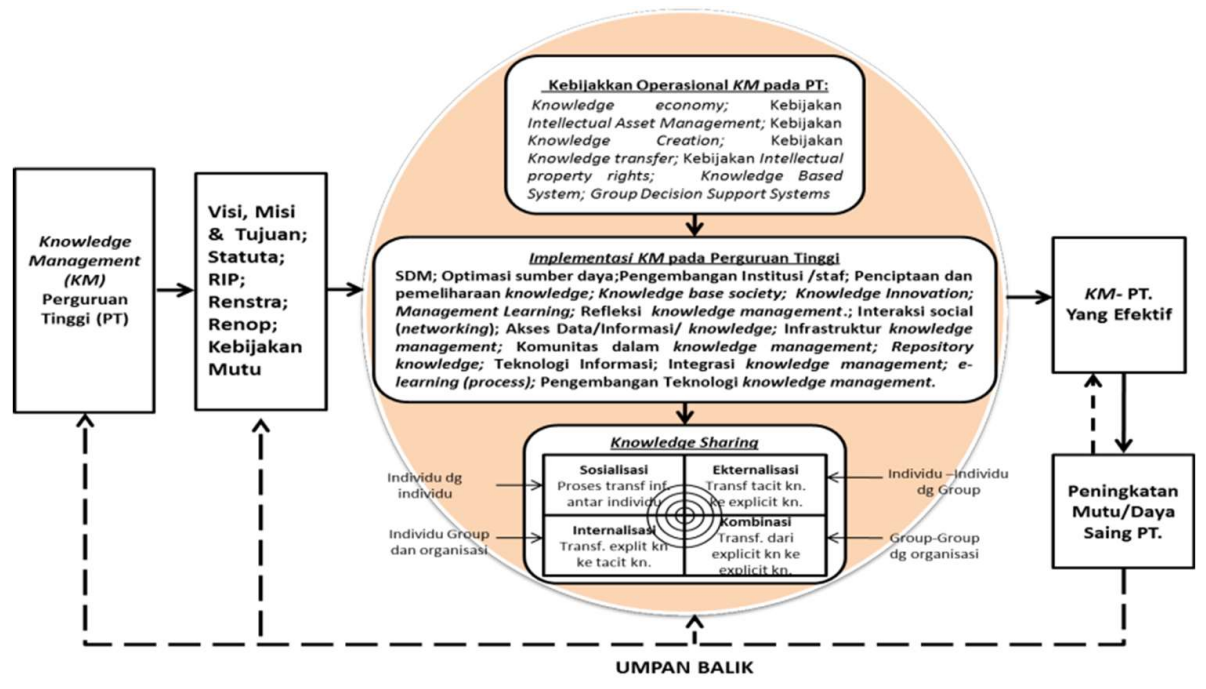

Gambar 3.1 Model Hipotetik Peningkatan Implementasi Knowledge Management di Perguruan Tinggi Secara Efektif

\section{PENUTUP (Kesimpulan dan Saran)}

Evaluasi implementasi kampiun berdasarkan pengukuran kinerja dinyatakan bahwa pengukuran kinerja pegawai berdasarkan pengetahuan kampiun apabila dikategorikan memiliki nilai sedang sebesar $42 \%$. Sehingga dapat disimpulkan bahwa pengatahuan dalam kampiun belum digunakan oleh seluruh pegawai untuk membantu pekerjaannya. Hanya beberapa pegawai saja yang sudah memanfaatkannya untuk membantu kinerja pekerjaan. Padahal pengetahuan dalam kampiun dapat membantu pegawai menyelesaikan dan mendukung pekerjaannya. Beberapa pegawai telah menyatakan bahwa pengetahuan dalam kampiun dapat menjadi sumber untuk menyelesaikan pekerjaan dan membantu memperbaiki kesalahan yang terdapat pada beberapa sub pengetahuan sesuai unit kerja pegawai. Serta dengan menggunakan pengetahuan dari kampiun dapat menciptakan efisiensi dalam melakukan pekerjaan, membantu pengambilan keputusan, membuat pegawai puas atas pengetahuan dalam kampiun, menjadikan pegawai lebih sering berbagi pengetahuan sehubungan dengan pekerjaannya serta menjadikan pegawai dapat lebih berinovasi. Dengan adanya hasil tersebut maka sejauh ini dapat dinyatakan bahwa pengetahuan dalam kampiun belum mampu untuk membantu kinerja pegawai. Padahal klasifikasi pengetahuan yang sesuai dengan sub unit pekerjaan sebenarnya dapat sangat membantu pegawai untuk bisa langsung merujuk kebutuhan pengetahuan sesuai dengan unit kerja yang dinaungi. Karena memang tujuan kampiun sendiri adalah sebagai alat untuk menciptakan budaya knowledge management pada organisasi PT Telkom.

Dukungan kebijakan operasional knowledge management di ITB dilihat dari beberapa aspek menunjukkan telah diselaraskan dengan 
tridharma perguruan tinggi, yang berorientasi pada peningkatan kualitas dan kemampuan sumber daya manusia berbasis inovasi menuju keunggulan kompetitif perguruan tinggi. Namun demikian, ITB sebagai universitas riset, dalam mempublikasi hasil produk knowledge baru mencapai prestasi optimal di tingkat nasional, sedangkan ditingkat Asia masih berada di bawah Singapura urutan pertama diduduki oleh National University of Singapure, Malaysia adalah University of Malaya, Thailand adalah Mahidol University. Kemudian terkait dengan kebijakan operasional sistem manajemen pengetahuan (knowledge management system) belum aspek manajemen asset intelektual, penciptaan pengetahuan (knowledge creation), transfer pengetahuan (knowledge transfer), dan sistem berbasis pengetahuan (knowledge based system), penetapan kebijakannya belum komprehensip tetapi masih parsial mendapatkan izin resmi untuk memberikan Indonesian Most Admired Knowledge Enterprise (MAKE) Award kepada organisasiorganisasi yang paling dikagumi dalam implementasi knowledge management di Indonesia (www.dunamis.co.id). Implementasikan knowledge management belum dijadikan visi strategis, melalui misinya untuk mencapai tujuan yang komprehensif dengan menggabungkan bagian-bagian organisasi menjadi satu kesatuan: orang (people), proses, dan teknologi diselaraskan dengan fokus peningkatan tridharma perguruan tinggi.

Berbagi pengetahuan (knowledge sharing) di perguruan tinggi seperti proses transfer informasi antar individu, transfer tacit knowledge ke explicit knowledge, transfer dari explicit knowledge ke explicit knowledge dan transfer explicit knowledge ke tacit knowledge untuk dapat dimanfaatkan oleh pihak-pihak yang berkepentingan belum optimal. Knowledge sharing belum sepenuhnya terintegrasi antara orang (people), proses, dan teknologi informasi masih secara offline.

Model pengembangan knowledge management pada perguruan tinggi belum memiliki standar baku untuk dijadikan visi strategis, dengan menggabungkan bagian-bagian organisasi menjadi satu kesatuan: orang (people), proses, dan teknologi diselaraskan dengan fokus peningkatan tridharma perguruan tinggi sebagai upaya untuk meningkatkan mutu dan daya saing perguruan tinggi dalam menghadapi kompetitornya baik di tingkat regional, nasional maupun global.

\section{DAFTAR PUSTAKA}

Al-Gharibeh, K.M. (2011) The Knowledge Enablers of Knowledge Transfer: An Empirical Study in Telecommunications Companies. IBIMA Publishing. http://www.ibimapublishing.com/jo urnals/I BIMABR/ibimabr.html.Vol. 2011, Article ID 328944, $\quad 13$ pages DOI: 10.5171/2011.32894.

Dalkir, K. (2005). Knowledge Management In Theory and Practice. USA Linacre House, Jordan Hill, Oxford OX2 8DP, UK Elsevier Butterworth-Heinemann 30 Corporate Drive, Suite 400, Burlington, MA 01803.

Nonaka,I at.al (2008) Managing Flow A Process Theory of the Knowledge-Based Firm. PALGRAVE MACMILLAN Houndmills, Basingstoke, Hampshire RG21 6XS and 175 
Fifth Avenue, New York, N.Y. 10010.

Petrides, L.A. \& Nguyen, L. (2006) Knowledge Management Trends: Challenges and Opportunities for Educational Institutions. Metcalfe, Amy Scott (editor), Knowledge Management and Higher Education. A Critical Analysis (hlm 21-33). Published in the United States of America by Information Science Publishing (an imprint of Idea Group Inc.) 701 E. Chocolate Avenue Hershey PA 17033.

Polanyi, M. (1962) Personal Knowledge Towards a postcritical philosophy. Routledge is an imprint of the Taylor \& Francis Group.This edition published in the Taylor \& Francis e- Library, 2005.

Undang-Undang Republik Indonesia Nomor 12 Tahun 2012 Tentang Pendidikan Tinggi.

Undang-Undang Republik Indonesia Nomor 20 Tahun 2003 Tentang Sistem Pendidikan Nasional.

Uriarte, Jr. F.A. (2008) Introduction to Knowledge Management. Published by the ASEAN Foundation, Jakarta, Indonesia.

Sangkala. Knowledge Management: Pengantar Memahami Bagaimana Organisasi Mengelola Pengetahuan Sehingga Menjadi Organisasi Yang Unggul. 2007. Jakarta : Raja Grafindo Persada

Sedarmayanti. Sumber Daya Manusia dan Produktivitas Kerja. 2001. Bandung : Mandar Maju

Tiwana, Amrit. The Knowledge Management Toolkit. 1999. USA : Prentice Hall PTR Tobing, Paul L. Knowledge
Management: Konsep, Arsitektur dan Implementasi.2007. Yogyakarta : Graha Ilmu

Widayana, Lendy. Knowledge Management: Meningkatkan Daya saing Bisnis. 2005. Malang : Bayu Media 